\title{
Influence of Pyrazosulfuron-Ethyl on Soil Microflora, Weed Count and Yield of Transplanted Rice (Oryza sativa L.)
}

\author{
Rajinder Kumar*, Ankit Rana, S.S. Rana, M.C. Rana, \\ Neelam Sharma and G.D. Sharma
}

Department of Agronomy, Forages and Grassland Management, CSK HPKV, Palampur (HP)-176 062, India

*Corresponding author

\begin{tabular}{|l|}
\hline Ke y w o r d s \\
Bacteria, Fungi, \\
Actinomycetes, \\
Herbicides and rice \\
\hline Article Info \\
\hline $\begin{array}{l}\text { Accepted: } \\
\text { 17 January } 2018 \\
\text { Available Online: } \\
\text { 10 February } 2018\end{array}$ \\
\hline
\end{tabular}

\section{Introduction}

More than half of the world human race depends on rice (Oryza sativa L.) for their daily sustenance (Chauhan and Johnson, 2011). In India, it is a staple food for millions of people. One of the major constraints in rice production is competition from weeds.
The use of herbicides in rice may affect the soil's biological equilibrium and thus influences its nutrient status, health and productivity. To know about the effect of herbicides on soil microbial populations in rice, a field experiment was conducted at Palampur during kharif 2016 and 2017. Ten treatments, comprised of company released sample of pyrazosulfuron-ethyl 10\% WP at 10, 15, 20 and $30 \mathrm{~g}$ ai/ha was compared to market sample at 10 and $15 \mathrm{~g} / \mathrm{ha}$, bispyribac- sodium at 20 and $40 \mathrm{~g} / \mathrm{ha}$, hand weeding twice and weedy check on a silty clay loam soil. The prevalence of Echinochloa crusgalli, E. colona, Cyperus difformis, C. iria, and Ammannia baccifera were the major weeds associated with rice crop. The results revealed great influence of different doses of preemergence (PE) pyrazosulfuron-ethyl 10\% WP on the population of total bacteria, fungi and actinomycetes initially after 5th day of its application (9 DAT). Pyrazosulfuron-ethyl $10 \% \mathrm{WP}$ at $30 \mathrm{~g}$ ai/ha exerted maximum reduction in bacterial, fungal and actinomycetes population in the tune of $20.86,26.39$ and $14.12 \%$, respectively. Post-emergence (POE) bispyribac sodium $40 \mathrm{~g} / \mathrm{ha}$ was found to reduce the population of bacteria, fungi and actinomycetes by $21.28,28.81$ and $15.29 \%$, respectively, after 5 days of herbicide application (30 DAT). The market sample of pyrazosulfuron-ethyl $10 \% \mathrm{WP} 15 \mathrm{~g} / \mathrm{ha}$ showed higher reduction on 5 days after spray over the company sample. The population of microorganisms under observation was recovered from initial herbicide impact on 15 days after their spray. Pyrazosulfuron $30 \mathrm{~g} / \mathrm{ha}$ remaining at par with pyrazosulfuron 20 $\mathrm{g} / \mathrm{ha}$ gave significantly higher yield of rice over other weed control treatments. 
to be produced by 2035 which is equivalent to an overall increase of $26 \%$ in the next 25 years (Kumar and Ladha, 2011). Proper weed management is, therefore, essential to realize the potential yield of high yielding rice varieties.

An assessment of the performance of different herbicides, which can provide wide weed control spectrum in transplanted rice, will be useful for evolving an economically viable and environmentally safe weed management strategy for transplanting rice. Among new molecules, sulfonylureas, comprises the most widely low dose high efficacy (LDHE) (Brown, 1990) used herbicides in the present day agriculture (Rao, 2000).

Among the various LDHE herbicides pyrazosulfuron ethyl is very effective against grasses, sedges and broad leaved weeds in rice (Moorthy, 2002). Another new molecule, bispyribac-sodium is a post-emergence herbicide for the control of a wide range of weeds with excellent selectivity on directseeded Indica-type rice. Bispyribac sodium is a potential post-emergence herbicide in transplanted rice applied from 1-7 leaf stage of the weed.

The use of these PE and POE herbicides in transplanted rice is paramount to assess their tendency to cause any adverse effect on soil microflora in rice at different stages of growth. A healthy population of soil microorganisms can stabilize the ecological system in soil (Chauhan et al., 2006). Any change in their population and activity may affect nutrient cycling as well as availability of nutrients which indirectly affect productivity and other soil functions (Wang et al., 2008). It is also reported that one of the possible causes of productivity decline in rice cropping system is the change in soil microflora (Reichardt et al., 1998). Keeping these points in mind the present investigation was undertaken.

\section{Materials and Methods}

The investigation was carried out during kharif 2015 and 2016 at Agronomy Farm, College of Agriculture, CSK Krishi Vishvavidyalaya, Palampur. Geographically, it is situated at $32^{\circ} 6^{\prime} \mathrm{N}$ latitude, $76^{\circ} 3^{\prime} \mathrm{E}$ longitude and $1290.8 \mathrm{~m}$ altitude. This area represents mid hill sub-humid climatic zone of Himachal Pradesh. The total annual rainfall received during the 2016-17 cropping season at the centre was $2689 \mathrm{~mm}$ (129 rainy days), out of which $84.4 \%$ is received during monsoon period (June to September) and $15.6 \%$ during October to March. May was the hottest month $\left(23.7{ }^{\circ} \mathrm{C}\right)$ followed by July and June. January was the coldest month having mean temperatures of $10.1{ }^{\circ} \mathrm{C}$ followed by December with average temperature of 13.2 ${ }^{\circ} \mathrm{C}$. The mean daily evaporation from US open pan evaporimeter was $3.0 \mathrm{~mm}$. The mean evaporation per day ranges from $1.4 \mathrm{~mm}$ in July/August 2016 to $5.6 \mathrm{~mm}$ in June. The mean relative humidity remained between 67.3 to $89 \%$ from June to September and 48.1 to $81.2 \%$ for rest of the period. The soil of the experimental field was silty clay loam in texture, acidic in reaction ( $\mathrm{pH} 5.2)$, medium in organic matter $(0.96 \%)$, available N (242 $\mathrm{kg} / \mathrm{ha})$ and $\mathrm{P}(21.2 \mathrm{~kg} / \mathrm{ha})$ and high in available K (330.7 kg/ha).

Ten treatments comprising of company released samples of pyrazosulfuron-ethyl $10 \%$ WP at 10, 15, 20 and $30 \mathrm{~g}$ ai/ha was compared with market samples of pyrazosulfuron ethyl $10 \% \mathrm{WP}$ at $10,15 \mathrm{~g}$ ai/ha, bispyribac sodium 20 and $40 \mathrm{~g} / \mathrm{ha}$, hand weeding twice and weedy check were tested in randomized block design with three replications. Rice variety HPR 2143 was transplanted on 7 July 2016 and 15 July 2017. The crop was fertilized with $90 \mathrm{~kg} \mathrm{~N}, 40 \mathrm{~kg} \mathrm{P}_{2} \mathrm{O}_{5}$ and $40 \mathrm{~kg} \mathrm{~K}_{2} \mathrm{O} / \mathrm{ha}$ through urea, single super phosphate and muriate of potash, respectively. The required quantity of half $\mathrm{N}$ and whole $\mathrm{P}_{2} \mathrm{O}_{5}$ and $\mathrm{K}_{2} \mathrm{O}$ 
was drilled at sowing. The remaining half $\mathrm{N}$ was band placed at 55 DAS. The herbicide was sprayed on 11 July 2016 and 19 July 2017 with power sprayer using 6001 water/ha.

Enumeration of the soil microbial population was carried out just before spraying the herbicide, $5^{\text {th }}$ days after herbicide application, i.e. 9 DAT, 19DAT, 34DAT, 44DAT, 64 DAT and at harvest. Total count of bacteria, fungi and actinomycetes was assessed by serial dilution plate technique (Wollum, 1982). Ten gram of soil was added to $90 \mathrm{ml}$ of sterilized distilled water in a $250 \mathrm{ml}$ conical flask under aseptic condition and shaken for 30 minutes in a orbital shaker for uniform mixing for obtaining $10^{-1}$ dilution. With a sterile pipette, $1 \mathrm{ml}$ of $10^{-1}$ dilution was transferred to $9 \mathrm{ml}$ sterile water blank and mixed well to obtain a $10^{-2}$ dilution and so on to get further dilutions of $10^{-3}, 10^{-4}, 10^{-5}$ and $10^{-6}$. One $\mathrm{ml}$ aliquot of desired dilutions was transferred aseptically to sterile petri dishes to enumerate of bacteria, fungi and actinomycetes population. Nutrient agar, potato dextrose agar and actinomycetes agar media were used for enumerating the population of bacteria, fungi and actinomycetes in the soil samples. Plates were incubated at $28^{\circ} \mathrm{C} \pm 2^{\circ} \mathrm{C}$ for bacteria and actinomycetes and $22.5 \pm 2^{\circ} \mathrm{C}$ for fungi. Observations were taken after 2 days in the case of bacteria, 3 days for fungi and 6-7 days for actinomycetes. The colonies were counted and the number of viable bacteria, fungi and actinomycetes expressed as colony forming units (cfu) per gram dry weight of soil was estimated by taking into account the soil dilutions. The data were subjected to statistical analysis by analysis of variance (ANOVA) for the randomized block design to test the significance of the overall differences among the treatments by the " $F$ " test and conclusion was drawn at 5\% probability level. Standard error of mean was calculated in each case. When the ' $\mathrm{F}$ ' value from analysis of variance tables was found significant, the critical difference was computed to test the significance of the difference between the two treatments.

\section{Results and Discussion}

\section{Effect of herbicides on weeds}

The major weeds found growing in association with transplanted rice during kharif were Echinochloa crusgalli (16.7\%), E. Colona (14.8\%), Cyperus difformis (20.2\%), C. Iria (9.5\%), and Ammannia baccifera (37.7\%). There was a little shift in the weed flora in the next year and Echinochloa colona (16.7\%), Cyperus difformis (22.64\%) and Ammannia baccifera $(42.49 \%)$ were the major weeds at 60 DAT during kharif 2017. Weed control treatments brought about significant variation in the count of grasses, sedges and broadleaved weeds (Table 1). All weed control treatments were significantly superior to weedy check in curtailing the population of grasses, sedges and broadleaved weeds. Hand weeding twice resulted in significantly lower count of all categories of weeds. Control of weeds increased with increase in the dose of pyrazosulfuron but differences due to doses were not significant. Pyrazosulfuron gave control of weeds comparable to that with bispyribac sodium. The effective control of grasses, sedges and broad-leaved weeds with pyrazosulfuron (Saini et al., 2008) and bispyribac sodium (Kumar and Rana 2013; Kumar et al., 2013) in rice has been reported.

\section{Effect of herbicides on soil microorganisms}

\section{Bacterial population}

Different doses of pyrazosulfuron-ethyl as PE and bispyribac-Sodium as POE brought about significantly variation in bacterial population in soil at different growth stages of rice crop (Table 2). Pyrazosulfuron-ethyl was applied 4 DAT and bispribac 25 DAT during 2017. The 
initial bacterial population immediately after spray of herbicide was not affected significantly due to treatments. After the pyrazosulfuron treatment, there was drastic reduction in bacteria population in soil. The bacterial population was significantly low at $5^{\text {th }}$ day after pyrazosulfuron-ethyl application in crop. The maximum reduction was found in $\mathrm{T}_{4}$ : pyrazosulfuron ethyl @ $30 \mathrm{~g}$ a.i./ha $(20.86 \%)$ and minimum in ${ }_{T 1}$ : pyrazosulfuron ethyl @ 10g a.i./ha (14.66\%). The application of bispyuribac-sodium was found to reduce the bacterial population at higher rate in $\mathrm{T}_{7}$ and $\mathrm{T}_{8}$ five days after their treatment (30 DAT).

The maximum reduction was in $\mathrm{T}_{8}$, Bispyribac-Sodium $\quad 40 \mathrm{~g}$ a.i./ha (21.28\%). Market sample of pyrazosulfuron ethyl 10\% WP at $10,15 \mathrm{~g}$ ai/ha had higher rate of reduction in the soil bacterial population as compared to the company samples. The population of the bacteria was gradually regained at 60 DAT. There was higher population of soil bacteria in the hand weeded and weedy check plots throughout the crop growing season from 0 DAS to 60 DAS and then insignificant reduction in bacterial population after $60 \mathrm{DAS}$. At harvest, treatment differences were not significant which showed that there was no long lasting effect of the herbicide on soil bacteria.

It could be further inferred that the bacterial population started to regain after the weeds killed by the herbicides. After being mixed in the soil weeds might have served to increase the nutrients. The degradation of herbicides may be serving as a carbon source for growth of microbes. These results were in tune with finding of Jarvan et al., (2014). The bacterial population in herbicide treated plots was more or less similar to the unsprayed control plots in later stages indicating that herbicides have no long lasting detrimental effect on soil health at applied doses. Anderson (2003) reported that herbicides generally appear to have no adverse effect on total bacterial population in soil except at concentrations exceeding recommended rates.

\section{Fungal population}

The perusal of data in Table 3 revealed significant variation in the fungal population at 5 days after application of pre-emergence pyrazosulfuron. Among different herbicides doses, pyrazosulfuron-ethyl 10\% WP (30g ai/ha) inhibited the fungal growth at higher rate $(26.69 \%)$ at 5 DAS. The application of bispyuribac-sodium also reduced the fungal population $(28.81 \%)$ after 5 days of herbicide application (30 DAT). At harvest, the fungal population under herbicidal treatments was comparable to control. Similar results were obtained by Spandana Bhatt et al., (2017) who also found variation in the population of soil fungi during the entire crop period. Maximum reduction in the population of fungi was observed at 3 days after herbicide application. As similar as in present study, Roberts (1998) also concluded that microbial activities were more sensitive to herbicides leading to slight initial suppressing effect. The degradation of herbicides in rice fields was augmented by high temperatures which usually stabilize in range favouring high microbial activity. After initial reduction, fungi population found to increase due to herbicidal treatments and by the termination of growing period on par with unsprayed plots (hand weeding and weedy check).

Poornima Yadav et al., (2015) also revealed initial inhibition in fungi population and thereafter completes recovery within 30 days after spraying with the application of pyrazosulfuron-ethyl and butachlor. The adaptation to these herbicides or degradation of the herbicides by soil fungi might have made it possible. 
Table.1 Effect of treatments on count of grasses, sedges and broad-leaved weeds in transplanted rice at 60 DAT (2017)

\begin{tabular}{|c|c|c|c|c|c|}
\hline Treatment & $\begin{array}{c}\text { Dose (g } \\
\text { ai/ha) }\end{array}$ & Grasses & Sedges & Broadleaved & Total \\
\hline \multirow{2}{*}{$\mathrm{T}_{1}$-Pyrazosulfuron -ethyl $10 \% \mathrm{WP}$} & \multirow[t]{2}{*}{10} & 12.8 & 11.2 & 19.7 & 43.7 \\
\hline & & $(21.3)$ & $(37.3)$ & $(69.3)$ & $(128)$ \\
\hline \multirow{2}{*}{$\mathrm{T}_{2}$ - Pyrazosulfuron -ethyl $10 \% \mathrm{WP}$} & \multirow[t]{2}{*}{15} & 13.3 & 10.7 & 16.5 & 40.5 \\
\hline & & $(26.7)$ & $(37.3)$ & $(58.7)$ & $(122.7)$ \\
\hline \multirow{2}{*}{$\mathrm{T}_{3}$ - Pyrazosulfuron -ethyl $10 \% \mathrm{WP}$} & \multirow[t]{2}{*}{20} & 11.7 & 6.9 & 12.3 & 30.9 \\
\hline & & $(21.3)$ & $(21.3)$ & $(58.7)$ & $(101.3)$ \\
\hline \multirow{2}{*}{$\mathrm{T}_{4}$ - Pyrazosulfuron -ethyl $10 \% \mathrm{WP}$} & \multirow[t]{2}{*}{30} & 10.7 & 7.5 & 10.1 & 28.3 \\
\hline & & $(16.0)$ & $(26.7)$ & $(42.7)$ & $(85.3)$ \\
\hline \multirow{2}{*}{$\mathrm{T}_{5}$ - Pyrazosulfuron -ethyl 10\% WP (Market sample) } & \multirow[t]{2}{*}{10} & 16.5 & 13.3 & 19.2 & 49.1 \\
\hline & & $(26.7)$ & $(48.0)$ & $(69.3)$ & $(144)$ \\
\hline \multirow{2}{*}{$\mathrm{T}_{6}$ - Pyrazosulfuron -ethyl 10\% WP (Market sample) } & \multirow[t]{2}{*}{15} & 11.2 & 11.2 & 17.6 & 40 \\
\hline & & $(21.3)$ & $(37.3)$ & $(69.3)$ & $(128)$ \\
\hline \multirow{2}{*}{ T7-Bispyribac - Sodium } & \multirow[t]{2}{*}{20} & 22.9 & 10.7 & 17.1 & 50.7 \\
\hline & & $(37.3)$ & $(37.3)$ & $(58.7)$ & $(133.3)$ \\
\hline \multirow{2}{*}{ T8- Bispyribac - Sodium } & \multirow[t]{2}{*}{40} & 14.4 & 8.0 & 11.2 & 33.6 \\
\hline & & $(21.3)$ & $(26.7)$ & $(42.7)$ & $(90.7)$ \\
\hline \multirow{2}{*}{ T9-Hand weeding twice } & & 5.9 & 2.7 & 6.9 & 15.5 \\
\hline & & $(10.7)$ & $(10.7)$ & $(26.7)$ & $(48)$ \\
\hline \multirow{2}{*}{$\mathrm{T}_{10}$ - weedy check } & & 20.8 & 19.7 & 21.3 & 61.9 \\
\hline & & $(37.3)$ & $(80.0)$ & $(80.0)$ & (197.3) \\
\hline $\mathrm{SE}(\mathrm{m} \pm)$ & & 1.2 & 0.7 & 1.1 & 0.9 \\
\hline $\operatorname{LSD}(\mathrm{P}=0.05)$ & & NS & 2.2 & NS & 2.7 \\
\hline
\end{tabular}

Figures in parentheses are the means of original values

DAT-Day after transplant

Table.2 Effect of herbicides application on soil bacterial population (x10 $/ \mathrm{g}$ soil) in rice field during 2017

\begin{tabular}{|c|c|c|c|c|c|c|c|c|}
\hline \multirow{4}{*}{ Treatment } & \multirow{4}{*}{$\begin{array}{c}\text { Dose } \\
(\mathrm{g} \\
\text { ai/ha) }\end{array}$} & \multirow{4}{*}{$\begin{array}{c}\text { 0 } \\
\text { DAS }\end{array}$} & & \multicolumn{2}{|c|}{ Total Bacteria } & & & \multirow{4}{*}{$\begin{array}{c}\text { At } \\
\text { Harvest }\end{array}$} \\
\hline & & & \multirow{3}{*}{ 5DAS } & \multirow{3}{*}{ 15DAS } & \multirow{3}{*}{ 30DAS } & \multirow{3}{*}{ 40DAS } & \multirow{3}{*}{ 60DAS } & \\
\hline & & & & & & & & \\
\hline & & & & & & & & \\
\hline T1-Pyrazosulfuron -ethyl 10\% WP & 10 & 53.67 & 45.80 & 54.12 & 55.50 & 58.15 & 61.68 & 57.35 \\
\hline $\mathrm{T}_{2}$ - Pyrazosulfuron -ethyl 10\% WP & 15 & 53.38 & 44.83 & 54.05 & 55.05 & 57.34 & 60.22 & 56.32 \\
\hline T3- Pyrazosulfuron-ethyl 10\% WP & 20 & 52.52 & 43.10 & 53.64 & 54.84 & 56.85 & 59.02 & 55.68 \\
\hline T4- Pyrazosulfuron -ethyl 10\% WP & 30 & 53.02 & 41.96 & 53.33 & 54.02 & 56.42 & 58.88 & 55.55 \\
\hline T5- Pyrazosulfuron -ethyl 10\% WP (Market sample) & 10 & 53.42 & 44.23 & 53.70 & 54.75 & 57.22 & 60.07 & 55.74 \\
\hline T6- Pyrazosulfuron -ethyl 10\% WP (Market sample) & 15 & 53.27 & 43.32 & 53.44 & 53.94 & 56.99 & 58.94 & 54.60 \\
\hline T7-Bispyribac - Sodium & 20 & 53.71 & 56.49 & 59.80 & 48.41 & 56.45 & 58.07 & 53.97 \\
\hline T8- Bispyribac - Sodium & 40 & 53.46 & 55.12 & 57.90 & 45.58 & 55.27 & 57.80 & 52.29 \\
\hline T9-Hand weeding twice & & 53.24 & 55.05 & 57.84 & 57.83 & 60.01 & 64.83 & 55.83 \\
\hline T10- weedy check & & 52.96 & 55.55 & 56.77 & 57.78 & 59.86 & 62.11 & 54.11 \\
\hline $\mathrm{SE}(\mathrm{m} \pm)$ & & 1.84 & 2.91 & 1.69 & 1.16 & 0.37 & 2.63 & 1.62 \\
\hline $\operatorname{LSD}(\mathrm{P}=0.05)$ & & NS & 6.12 & 3.57 & 2.45 & 0.79 & NS & NS \\
\hline
\end{tabular}

DAS- Day After Sowing 
Table.3 Effect of herbicides application on soil fungal population (x10 $/ \mathrm{g}$ soil) in rice field

\begin{tabular}{|c|c|c|c|c|c|c|c|c|}
\hline \multirow[b]{2}{*}{ Treatment } & \multirow{3}{*}{$\begin{array}{r}\text { Dose } \\
\text { (g ai/ha) }\end{array}$} & \multirow{3}{*}{0 DAS } & \multirow{3}{*}{ 5DAS } & \multicolumn{2}{|c|}{ Total Fungi } & \multirow{3}{*}{ 40DAS } & \multirow{3}{*}{ 60DAS } & \multirow{3}{*}{ At Harvest } \\
\hline & & & & \multirow{2}{*}{ 15DAS } & \multirow[t]{2}{*}{ 30DAS } & & & \\
\hline & & & & & & & & \\
\hline T1-Pyrazosulfuron -ethyl 10\% WP & 10 & 33.18 & 27.18 & 33.53 & 34.77 & 36.61 & 38.22 & 30.63 \\
\hline $\mathrm{T}_{2}$ - Pyrazosulfuron -ethyl 10\% WP & 15 & 33.66 & 26.47 & 33.69 & 35.91 & 36.14 & 38.84 & 30.09 \\
\hline T3- Pyrazosulfuron -ethyl 10\% WP & 20 & 33.21 & 24.89 & 33.65 & 35.46 & 35.96 & 37.15 & 29.68 \\
\hline T4- Pyrazosulfuron -ethyl 10\% WP & 30 & 32.25 & 23.64 & 33.31 & 35.62 & 35.05 & 37.99 & 29.64 \\
\hline T5- Pyrazosulfuron - ethyl 10\% WP (Market sample) & 10 & 32.63 & 26.34 & 32.67 & 34.85 & 35.72 & 36.49 & 30.11 \\
\hline T6- Pyrazosulfuron - ethyl 10\% WP (Market sample) & 15 & 32.99 & 25.34 & 33.27 & 35.25 & 35.11 & 37.47 & 29.82 \\
\hline T7-Bispyribac - Sodium & 20 & 32.41 & 33.22 & 33.57 & 24.38 & 33.17 & 35.15 & 30.96 \\
\hline T8- Bispyribac - Sodium & 40 & 33.78 & 34.20 & 35.33 & 25.15 & 34.43 & 36.39 & 29.91 \\
\hline T9-Hand weeding twice & & 36.59 & 37.01 & 38.16 & 40.26 & 41.10 & 41.40 & 30.07 \\
\hline T10- weedy check & & 35.97 & 36.32 & 37.05 & 38.90 & 39.70 & 40.08 & 30.91 \\
\hline $\mathrm{SE}(\mathrm{m} \pm)$ & & 2.48 & 0.86 & 0.67 & 0.78 & 1.04 & 1.04 & 1.21 \\
\hline $\operatorname{LSD}(\mathrm{P}=0.05)$ & & NS & 1.80 & 1.41 & 1.65 & 2.20 & 2.21 & NS \\
\hline
\end{tabular}

\begin{tabular}{|c|c|c|c|c|c|c|c|c|c|c|c|}
\hline \multicolumn{12}{|c|}{ Table.4 Effect of herbicides application on soil actinomycetes population $\left(\times 10^{4} / \mathrm{g}\right.$ soil) in rice field } \\
\hline \multirow[b]{2}{*}{ Treatment } & \multirow{3}{*}{$\begin{array}{c}\text { Dose } \\
\text { (g ai/ha) }\end{array}$} & \multirow[b]{3}{*}{ 0 } & \multirow[b]{3}{*}{ 5DAS } & \multirow[b]{3}{*}{ 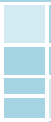 } & \multicolumn{3}{|c|}{ Total Actinomycetes } & \multirow[b]{3}{*}{ 40DAS } & \multirow[b]{3}{*}{$\square$} & \multirow[b]{3}{*}{ 60DAS } & \multirow{3}{*}{$\begin{array}{c}\text { At } \\
\text { Harvest }\end{array}$} \\
\hline & & & & & & & & & & & \\
\hline 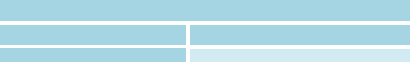 & & & & & 15DAS & - & 30DAS & & & & \\
\hline $\mathrm{T}_{1}$-Pyrazosulfuron -ethyl 10\% WP & 10 & 64.43 & 55.66 & & 64.68 & & 66.60 & 68.58 & & 69.08 & 65.11 \\
\hline $\mathrm{T}_{2}$ - Pyrazosulfuron -ethyl $10 \% \mathrm{WP}$ & 15 & 63.31 & 55.23 & & 63.42 & & 65.79 & 68.40 & & 68.94 & 64.15 \\
\hline $\mathrm{T}_{3}$ - Pyrazosulfuron -ethyl 10\% WP & 20 & 65.79 & 57.12 & & 64.33 & & 68.28 & 68.05 & & 68.55 & 63.20 \\
\hline $\begin{array}{c}\text { T6- Pyrazosulfuron -ethyl 10\% WP } \\
\text { (Market sample) }\end{array}$ & 15 & 62.14 & 53.00 & & 60.83 & & 65.43 & 68.14 & & 68.73 & 64.04 \\
\hline T7-Bispyribac - Sodium & 20 & 63.94 & 66.14 & & 67.35 & & 58.59 & 64.56 & & 65.92 & 64.25 \\
\hline T8- Bispyribac - Sodium & 40 & 63.57 & 65.98 & & 66.66 & & 56.47 & 63.03 & & 65.61 & 64.15 \\
\hline
\end{tabular}

Table.5 Effect of treatments on grain and straw yield of rice 2016-17

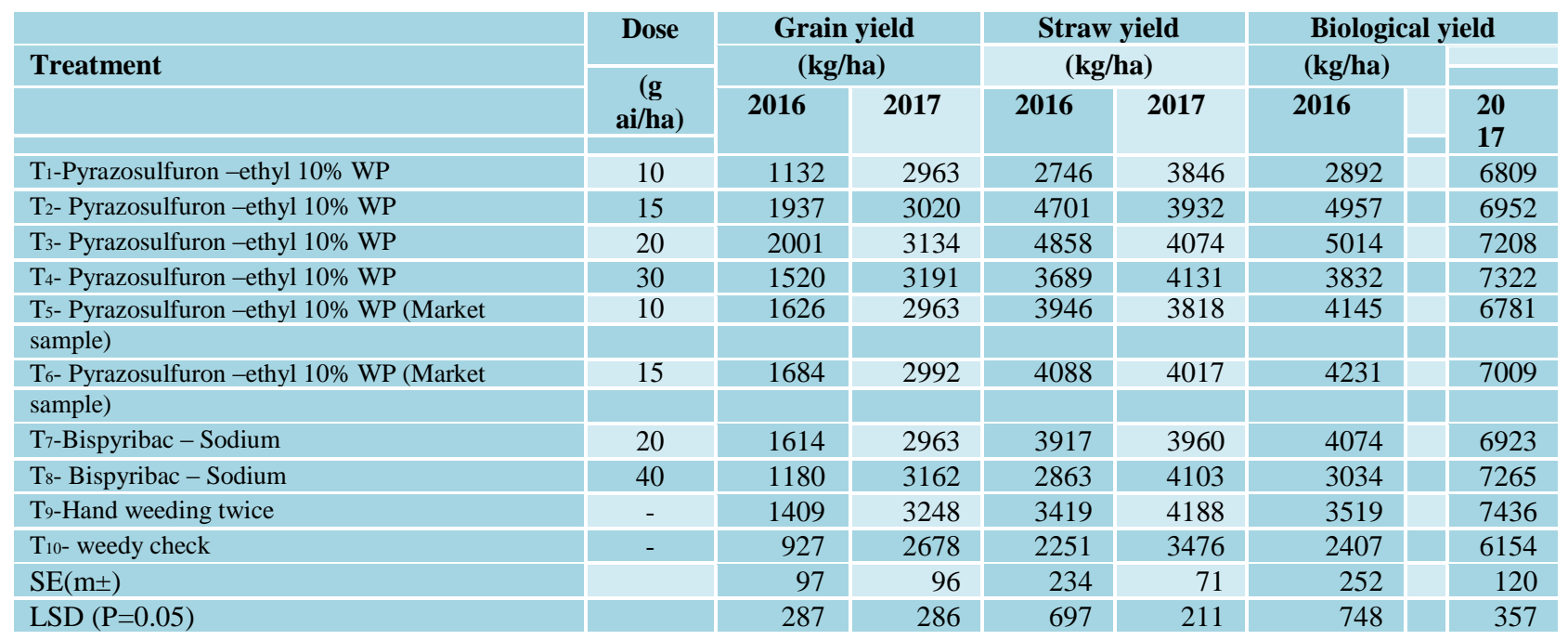




\section{Actinomycetes population}

The data on actinomycetes population in soil as affected by weed control treatments at different growth stages of rice have been shown in Table 4. Application of company as well as market samples of pyrazosulfuronethyl at different doses resulted in a decline in actinomycetes population soon after their application i.e. 5 DAS. The population then showed an increase from 15 DAS up to 60 DAS.

Application of bispyribac- sodium $\left(\mathrm{T}_{7}\right.$ and $\left.\mathrm{T}_{8}\right)$ revealed higher reduction in actinomycetes population on 5 DAS (30 DAT, 12.96 and $15.29 \%$, respectively). Thereafter, there was increasing trend from 15 DAS (40 DAT) up to 30 DAS (65 DAT). At harvest, differences in actinomycets population were not significant due to treatments showing no harmful residues of herbicides in soil analysed microbiologically. According to Beyer et al., (1988), the soil actinomycetes, Streptomyces griseolus rapidly metabolises chlorsulfuron.

Generally these micro-organisms are very important in the degradation of herbicides (Rao, 2000). Bera and Ghosh (2013) reported that microorganisms are able to degrade herbicides and utilize them as a source of biogenic elements for their own physiological processes.

However, before degradation, herbicides have toxic effects on microorganisms, reducing their abundance, activity and consequently, the diversity of their communities. The toxic effects of herbicides are normally severe immediately after application. Later on, microorganisms take part in a degradation process, and then the degraded organic herbicides provide carbon rich substrates which in turn maximize the microbial population in the rhizosphere.

\section{Effect of herbicide on crop}

Grain, straw and biological yield was significantly affected due to weed control treatments (Table 5). All treatments gave significantly higher yield of transplanted rice over the weedy check. Pyrazosulfuron $30 \mathrm{~g} / \mathrm{ha}$ remaining at par with pyrazosulfuron $20 \mathrm{~g} / \mathrm{ha}$ gave significantly higher yield over other weed control treatments.

Samples of pyrazosulfuron obtained directly from the industry had an edge over the market samples. The effectiveness of pyrazosulfuron (Saini et al., 2008) and bispyribac sodium (Kumar and Rana 2013; Kumar et al., 2013) in rice has been reported earlier also. Uncontrolled growth of weeds reduced the grain yield of transplanted rice by $30 \%$.

The findings of the present investigation clearly indicated the effectiveness of pyrazosulfuron ethyl as good as the standard herbicide bispyribac sodium in controlling weeds and increasing yield of rice.

However, there was little inhibition of bacteria, fungi and actinomycetes population for a small period of time in the cropping cycle which was recovered in the later stages up to harvest of the crop.

\section{References}

Anderson, T.H. 2003. Microbial eco-physiological indicators to assess soil quality, Agriculture, Ecosystems and Environment activities in two soils, Australian Journal of Soil Research. 36: 449-456.

Bera, S. and Ghosh, R.K. 2013. Soil Microflora and Weed Management as Influenced by Atrazine $50 \%$ WP in Sugarcane. Universal Journal of Agricultural Research. 1(2): 41-47.

Beyer E M, Duffy M J Jr, Hay J V, Schlueter D D. 1998. Sulfonyl ureas. Herbicides Chemistry, Degradation and Mode of Action (eds. Kearney, P.C. and Kaufman, D.D.). Merecl Dekker, New York; pp. 117-183. 
Brown H M. 1990. Mode of action, crop selectivity and soil relations of the sulfonyl urea herbicides. Pestic. Sci. 29: 263-281.

Chauhan A K, Das A, Kharkwal H, Kharkwal A C, Varma A. (2006). Impact of microorganisms on environment and Health. Microbes: Health and Environment; p286.

Chauhan BS, Johnson DE. 2011. Row spacing and weed control timing affect yield of aerobic rice. Field Crops Research; 121: 226-231.

Jarvan, M., Edesi, L. Adamson, A. Vosa, T. 2014. Soil microbial communities and dehydrogenase activity depending on farming systems. Plant Soil Environment. 60 (10): 459-463.

Kumar Suresh and SS Rana. 2013. Bioefficacy of Bispyribac-sodium for weed control in direct seeded rice. Pesticide Research Journal 25(2): 123-127.

Kumar Suresh, SS Rana, Navell Chander and Ramesh. 2013. Mixed weed flora management by bispyribac-sodium in transplanted rice. Indian Journal of Weed Science 45(3): 151-155.

Kumar V, Ladha JK. 2011. Direct-seeding of rice: recent developments and future research needs. Advance in Agronomy. 111:297-413

Moorthy B T S. 2002. Evaluation of pyrazosulfuron ethyl alone and in combination with molinate for controlling weeds in rainfed direct seeded lowland rice. Indian J. Weed Sci; 34: 285-286.

Oerke EC, Dehne HW. 2004. Safeguarding production losses in major crops and the role of crop protection. Crop Protection. 23:275285.

Poornima Yadav, P.I., Elizabeth. K. Syriac and Girija. V.K 2015. Response of Soil Microflora and Earthworms to Pyrazosulfuron Ehtyl, A New Generation Herbicide In Transplanted Rice In The Entisols Of Vellayani, South Kerala. Advance Research in Agriculture and Veterinary Science.2 (3 \& 4): $28-32$

Rao V S. 2000.Principles of Weed Science. Oxford and IBH publishing Co., New Delhi $555 \mathrm{p}$.

Reichardt W.A, Dobermann A, George T. 1998. Intensification of rice production systems: opportunities and limits. In Sustainability of rice in the global food System. Dowlin NG, Greenfield S M, Fisher K S (eds.). Pacific Basin Study Centre and IRRI Publ. Pp127144.

Roberts, T. R. 1998. Metabolic Pathways of Agrochemicals: Part 1. Herbicides and Plant Regulators, Royal Society of Chemistry. 8890.

Saini J P, S S Rana and Suresh Kumar 2008. Efficacy of pyrazosulfuron-ethyl with respect to dose and time of application against weeds in direct seeded rice (Oryza sativa). National symposium on New Paradigms in Agronomic Research, November 19-21, 2008, Navsari, Gujarat pp. 320-321.

Spandana Bhatt $\mathrm{P}$, Yakadri M, Madhavi M, Sridevi S and Leela Rani P. 2017. Influence of pre-emergence herbicides on the soil microflora during the crop growth of transplanted rice. International Journal of Agricultural Science and Research, 7(3):163172.

Wang Q K, Wang S L, LiunY X. 2008.Responses to $\mathrm{N}$ and $\mathrm{P}$ fertilization in a young Eucalyptus dunnii plantation; microbial properties, enzyme activities, and dissolved organic carbon. Appl. Soil Ecol; 40:484-490.

Wollum AG.1982. Cultural methods for soil microorganisms. In Methods of Soil Analysis ParT2. p781-813. American Society of Agronomy, Madison, Wisconsin, USA.

\section{How to cite this article:}

Rajinder Kumar, Ankit Rana, S.S. Rana, M.C. Rana, Neelam Sharma and Sharma, G.D. 2018. Influence of Pyrazosulfuron-Ethyl on Soil Microflora, Weed Count and Yield of Transplanted Rice (Oryza sativa L.). Int.J.Curr.Microbiol.App.Sci. 7(02): 1757-1764.

doi: https://doi.org/10.20546/ijcmas.2018.702.213 